\title{
Sustainable Construction-Use of Stone Dust as Plasticiser in High Strength SCC with Blended Cement
}

\author{
Tahir Kibriya ${ }^{1 *}$, Leena Tahir ${ }^{2}$ \\ ${ }^{1}$ Senior Consulting Engineer, Black \& Veatch, Toronto, Canada (ex Faculty/ Head of Civil Engineering Department, NUST, Risalpur, \\ Pakistan) \\ ${ }^{2} \mathrm{MSc}$ Structural Engineering, City University, London, UK \\ Email: ^t_kibriya@yahoo.com
}

How to cite this paper: Kibriya, T. and Tahir, L. (2017) Sustainable ConstructionUse of Stone Dust as Plasticiser in High Strength SCC with Blended Cement. World Journal of Engineering and Technology, 5, 412-420.

https://doi.org/10.4236/wjet.2017.53035

Received: May 19, 2017

Accepted: July 14, 2017

Published: July 17, 2017

Copyright $\odot 2017$ by authors and Scientific Research Publishing Inc. This work is licensed under the Creative Commons Attribution International License (CC BY 4.0).

http://creativecommons.org/licenses/by/4.0/

\begin{abstract}
Extensive growth in the developing countries due to infrastructure development is resulting into massive consumption of concrete thereby increasing the demand on concrete materials. Quite large amounts of fine aggregates are required for concrete in developing countries thus shortages of quality river sand is putting pressure on availability of fine aggregates. To fulfill the high demand of fine aggregates, a search for alternative materials is in process. Stone crushing and processing industry is a large industry which generates large amounts of stone dust and slurry which is a waste produced from this process. Tons of such waste generated has no useful purpose except as landfill material. Some preliminary studies have been conducted into use of marble/ limestone waste for use in concrete [1] [2]. This study aims at using stone dust as partial replacement of sand in concrete to observe its effects on workability and other mechanical properties. This would result in useful consumption of this waste product thereby eliminating environmental issues related to its disposal. Partial replacement of $10 \%$ and $20 \%$ sand replacement with stone dust is carried out with the use of self-compacting concrete with blended cement. Blended cement used contains 50\% rice husk ash and 50\% Portland cement. Such high strength SCC with blended cement containing 50\% rice husk ash and 50\% Portland cement has already been tested to provide better quality concrete [3]. Wide ranging investigations covering most aspects of mechanical behavior and permeability were carried out for various mixes for compressive strengths of $60 \mathrm{MPa} \& 80 \mathrm{MPa}$. Compressive strengths of high strength SCC with blended cements and $10 \%$ and $20 \%$ replacement of sand with stone dust for $60 \mathrm{MPa}$ and $80 \mathrm{MPa}$ were observed to be higher by about $10 \%$ to $13 \%$ than the control specimen. Higher elastic moduli and reduced permeability were observed along with better sulphate and acid resistance.
\end{abstract}


Better strengths and improved durability of such high strength SCC make it a more acceptable material for major construction projects thereby reducing the burden on environment and use of such waste product for a useful purpose promoting sustainable construction.

\section{Keywords}

Blended Cements, Stone Dust, Rice Husk Ash, Sustainable Construction, Industrial Waste, Agricultural Waste in Concrete

\section{Introduction}

Self-compacting concrete (SCC) is fresh concrete with superior flow ability under maintained stability (i.e. no segregation), allowing self-compaction. The three properties that characterize a concrete as self-compacting are flowing ability, passing ability and the ability to retain the coarse components of the mix in suspension in order to maintain a homogeneous material. High powder contents are needed in SCC to increase the cohesiveness. Large quantities of fine aggregates are required for concrete. Large consumption of concrete in the infrastructure development in the developing countries due to extensive growth has raised the demand on concrete materials. Huge demand of fine aggregates is resulting into shortages of quality river sand and is putting pressure on availability of fine aggregates. To fulfill the high demand of fine aggregates, various alternative materials are being considered as sand replacement materials. Huge amounts of stone dust and slurry is created as a waste product by the stone crushing and processing industry. Tons of such waste generated has no useful purpose except as landfill material. Stone dust has a very high Blaine fineness value of about 1.5 $\mathrm{m}^{2} / \mathrm{g}$ with $90 \%$ of particles passing $50 \mu \mathrm{m}$ sieves and $50 \%$ under $7 \mu \mathrm{m}$. Stone dust improves pozzolanic activity in concrete along with filling voids by better packing and improves concrete durability. The fineness modulus of rock dust is in the range of 2 to 2.2 as compared to 2.4 to 2.6 for fine sand. This study aims at using stone dust as partial replacement of sand in concrete to study its effects on workability and other mechanical properties of concrete. This would result in useful consumption of this waste product thereby eliminating environmental issues related to its disposal.

Partial replacement of $10 \%$ and $20 \%$ sand replacement with stone dust is carried out to study with the use of blended cement containing $50 \%$ rice husk ash and 50\% Portland cement. High strength SCC with blended cement containing $50 \%$ rice husk ash and 50\% Portland cement has already been tested to provide better quality concrete [3]-[10]. Wide ranging investigations covering most aspects of mechanical behavior and permeability were carried out for various mixes for compressive strengths of $60 \mathrm{MPa}, 80 \mathrm{MPa}$. Compressive strengths of high strength SCC with blended cement and containing $10 \%$ and $20 \%$ sand replacement with stone dust are observed to develop $10 \%$ to $13 \%$ higher compressive 
strengths, $7 \%$ to $9 \%$ higher flexural strength, $5 \%$ to $8 \%$ higher static moduli of elasticity with values up to $40,000 \mathrm{~N} / \mathrm{mm}^{2}$. Similarly $4 \%$ to $6 \%$ higher values for dynamic moduli for SCC with blended cement and containing $10 \%$ and $20 \%$ sand replacement with stone dust were observed with $4 \%$ to $8 \%$ higher pulse velocities, $3 \%$ to $4 \%$ higher density, up to $20 \%$ reduced permeability, similar shrinkage and two to three times improved sulphate and acid resistance as compared to control specimen. Better strengths and improved durability of such high strength SCC make it a more acceptable material for major construction projects

\section{Research Significance}

The significance of this research is to investigate the possible use of an abundantly available agricultural waste product i.e. stone dust in high strength SCC and to study the properties of such concrete.

\section{Design of Concrete Mixes}

In order to establish a procedure for mix design a linear projection of compressive strength versus w/c ratio from Design of Normal Concrete Mixes method was considered initially beyond the limiting $\mathrm{w} / \mathrm{c}$ ratio of 0.3 as given by Teychenne [11]. An initial estimate of density was made and later adjusted in the light of values actually obtained. Two high strength SCC mixes for characteristic strengths of 60 and $80 \mathrm{MPa}$ were designed using ordinary blended cement containing 50\% ordinary Portland cement and 50\% rice husk ash were used in addition to crushed natural calcareous limestone aggregates (maximum $20 \mathrm{~mm}$ diameter) and medium grade sand for the control mix. Two other mixes each for compressive strengths of 60 and $80 \mathrm{MPa}$ were termed Mix A and Mix B comprising of $10 \%$ replacement of medium sand with stone dust and $20 \%$ replacement of medium sand with stone dust, respectively were used for testing. Stone dust used was $100 \%$ passing $50 \mu \mathrm{m}$ with a fineness modulus of 2.2 and specific gravity of 2.8. Table 1 gives the details of basic mix design.

\section{Testing of Concrete}

Description of tests and samples used for various tests are given below in Table 2. Three specimen each from three different batches were used in all tests. All specimens were cured in water at $20^{\circ} \mathrm{C}$ for 28 days before testing.

\section{Discussion of Test Results}

The properties of the high performance concretes produced are summarized in Tables 3-5.

\subsection{Workability}

SCC with blended cement and containing $10 \%$ and $20 \%$ sand replacement with stone dust were observed to be $4 \%$ to $6 \%$ higher than the control mixes thereby improving the workability of concrete due to partial replacement of stone dust 
Table 1. Basic mix design.

\begin{tabular}{ccccccccc}
\hline $\begin{array}{c}\text { Characteristic Strength } \\
\text { MPa }\end{array}$ & \multicolumn{2}{c}{$\begin{array}{c}\text { W/C } \\
\text { Ratio }\end{array}$} & kg & kg & kg & $\begin{array}{c}\text { Sand } \\
\text { kg }\end{array}$ & $\begin{array}{c}\text { Water } \\
\text { 1/m }\end{array}$ & $\begin{array}{c}\text { Aggregate } \\
\%\end{array}$ \\
\hline 60 & 0.36 & 465 & 525 & 164 & 1290 & 46 & 0.04 \\
80 & 0.29 & 565 & 495 & 165 & 1210 & 7 & 0.06 \\
\hline
\end{tabular}

Table 2. Details of testing.

\begin{tabular}{cl}
\hline Type of Test & \multicolumn{1}{c}{ Test Sample } \\
\hline Compressive strength/density & $150 \mathrm{~mm}$ cubes, $150 \mathrm{~mm}$ diameter, $300 \mathrm{~mm}$ long cylinders \\
Flexural strength & $150 \times 150 \times 750 \mathrm{~mm}$ beams \\
Stress/strain behavior & $150 \mathrm{~mm}$ diameter, $300 \mathrm{~mm}$ long cylinders. \\
Static modulus of elasticity & $150 \mathrm{~mm}$ diameter, $300 \mathrm{~mm}$ long cylinders. \\
Dynamic modulus of elasticity & $150 \times 150 \times 750 \mathrm{~mm}$ beams. \\
Ultrasonic pulse velocity & $150 \mathrm{~mm}$ cubes. \\
Initial surface absorption & $150 \mathrm{~mm}$ cubes. \\
Density & $150 \mathrm{~mm}$ cubes \\
Sulphate and Chloride resistance & $\begin{array}{l}150 \mathrm{~mm} \text { cubes.(Immersed in } 5 \% \mathrm{H}_{2} \mathrm{SO}_{4} \text { and } 5 \% \mathrm{HCl} \\
\text { solutions for } 90 \text { days and measuring weight loss) }\end{array}$
\end{tabular}

Note: All specimen were cured in water at $200^{\circ} \mathrm{C}$ for 42 days before testing.

Table 3. Workability of concrete.

\begin{tabular}{ccc}
\hline W/C Ratio & Concrete mix & Slump in mm \\
\hline & Control & 590 \\
0.36 & Mix A & 630 \\
$60 \mathrm{MPa}$ & Mix B & 635 \\
& Control & 610 \\
0.29 & Mix A & 624 \\
$80 \mathrm{MPa}$ & Mix B & 635 \\
\end{tabular}

Note: Control-100\% Medium Sand; Mix A-10\% Replacement of sand with stone dust; Mix B-20\% Replacement of sand with stone dust.

Table 4. Properties of concrete specimen.

\begin{tabular}{ccccccc}
\hline $\begin{array}{c}\text { W/C } \\
\text { Ratio }\end{array}$ & Mixes & $\begin{array}{c}\text { Cube Strength } \\
\text { 7 Days MPa }\end{array}$ & $\begin{array}{c}\text { Cube Strength } \\
\text { 28 Days MPa }\end{array}$ & $\begin{array}{c}\text { Cube Strength } \\
\text { 42 Days MPa }\end{array}$ & $\begin{array}{c}\text { Cylinder } \\
\text { Strength MPa }\end{array}$ & $\begin{array}{c}\text { Flexural } \\
\text { Strength } \\
\text { MPa }\end{array}$ \\
\hline $\begin{array}{c}\text { 2.36 } \\
60 \mathrm{MPa}\end{array}$ & Mix A & 54 & 59 & 64 & 53.5 & 6.6 \\
& Mix B & 56 & 66 & 70 & 58 & 7.2 \\
0.29 & Control & 64 & 81 & 73 & 60 & 7.7 \\
$80 \mathrm{MPa}$ & Mix A & 72 & 84 & 84 & 71 & 8.2 \\
& Mix B & 74 & 87 & 87 & 74 & 9.3 \\
\hline
\end{tabular}


Table 5. Properties of concrete specimen.

\begin{tabular}{cccccc}
\hline $\begin{array}{c}\text { W/C } \\
\text { Ratio }\end{array}$ & Mixes & $\begin{array}{c}\text { ISAT } \\
\mathrm{ml} / \mathrm{m}^{2} / \mathrm{s}\end{array}$ & $\begin{array}{c}\text { Elastic Modulus } \\
\mathbf{N} / \mathrm{mm}^{2}\end{array}$ & $\begin{array}{c}\text { Dynamic Modulus } \\
\mathbf{N} / \mathrm{mm}^{2}\end{array}$ & $\begin{array}{c}\text { Pulse Velocity } \\
\mathrm{km} / \mathrm{s}\end{array}$ \\
\hline \multirow{2}{*}{0.36} & Control & 0.21 & 35,811 & 55,189 & 4.9 \\
$60 \mathrm{MPa}$ & Mix A & 0.18 & 37,916 & 56,231 & 5.1 \\
& Mix B & 0.15 & 39,324 & 57,219 & 5.2 \\
& Control & 0.19 & 36,198 & 56,561 & 5.2 \\
0.29 & Mix A & 0.14 & 38,232 & 57,952 & 5.4 \\
$80 \mathrm{MPa}$ & Mix B & 0.11 & 40,461 & 58,792 & 5.6 \\
\hline
\end{tabular}

with sand. Table 3 gives the slump measurements for various mixes.

\subsection{Compressive Strength}

Compressive strength tests on cubes at 7,28 and 42 days showed that the rate of development of strength of SCC with blended cement and containing $10 \%$ and $20 \%$ sand replacement with stone dust is similar to that for control specimen. The compressive strengths of SCC with blended cement and containing $10 \%$ and $20 \%$ sand replaced with stone dust is higher from $10 \%$ to $13 \%$ as compared to control mix. It was observed that compressive strengths kept increasing up to 42 days, as due to low w/c ratios, water is required from external sources for hydration of cement [12]. SCC with blended cement and containing $10 \%$ and $20 \%$ sand replacement with stone dust was observed to develop $80 \%$ to $85 \%$ of its 28-day characteristic strength in 7 days. Ratio of cylinder strength with cube strength for SCC with blended cement and containing 10\% and 20\% sand replacement with stone dust varies from $87 \%$ to $90 \%$ typically similar to control mixes. Failure of specimen of SCC with blended cement and containing $10 \%$ and $20 \%$ sand replacement with stone dust tends to be sudden and explosive, typical of high strength concretes as mentioned by Navy [13]. Sudden failure is likely to cause damage or injury hence a loading rate of 0.15 to $0.2 \mathrm{~N} / \mathrm{mm}^{2} / \mathrm{s}$ was observed to be safe enough as compared to 0.2 to $0.4 \mathrm{~N} / \mathrm{mm}^{2}$ specified by BS1881:Part 116:1983. Compressive strength test results for various specimen are given in Table 4.

\subsection{Flexural Strength}

Flexural strength of SCC with blended cement and containing 10\% and 20\% sand replacement with stone dust are observed to be higher by $7 \%$ to $9 \%$ as compared to control specimen. Better flexural strengths are a consequence of higher compressive strength and increased density of concrete with blended cement and containing $10 \%$ and $20 \%$ sand replacement with stone dust. Flexural strength of various specimen is given in Table 4.

\subsection{Stress/Strain Behavior}

It was observed that the general form of the stress/strain characteristics of SCC 


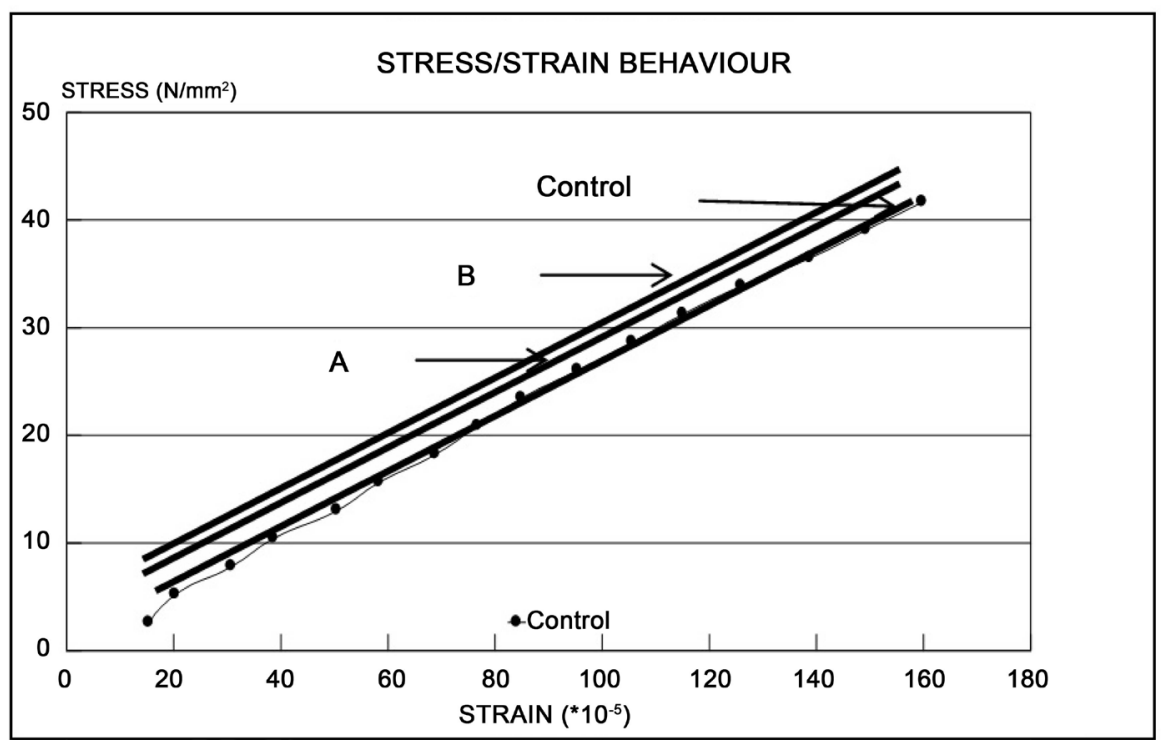

Note: Control-100\% Medium Sand; Mix A-10\% Replacement of sand with stone dust; Mix B$20 \%$ Replacement of sand with stone dust.

Figure 1. Idealised stress-strain curves.

with blended cement and containing $10 \%$ and $20 \%$ sand replacement with stone dust are observed similar to that for control specimen. All the curves were observed to be virtually linear up to the point of failure, except for the initial small portion, typical of high strength concretes. Higher moduli of elasticity were observed for SCC with blended cement and containing $10 \%$ and $20 \%$ sand replacement with stone dust are observed as compared to similar concrete with Portland cement only. Figure 1 shows the idealized stress-strain behavior of test samples.

\subsection{Static Modulus of Elasticity}

The average static modulus of elasticity for high strength SCC with blended cement and containing $10 \%$ and $20 \%$ sand replaced with stone dust are observed to be about $5 \%$ to $8 \%$ higher than the control specimen. Static modulus of elasticity was observed to be around 38,000 to $40,000 \mathrm{~N} / \mathrm{mm}^{2}$ for SCC with blended cement and containing $10 \%$ and $20 \%$ sand replacement with stone dust are observed to be $36,000 \mathrm{~N} / \mathrm{mm}^{2}$ for control mixes. Table 5 gives the values of static moduli of elasticity of various specimen.

\subsection{Dynamic Modulus of Elasticity}

The average dynamic modulus of elasticity for SCC with blended cement and containing $10 \%$ and $20 \%$ sand replacement with stone dust are observed to be the higher by about $4 \%$ to $5 \%$ than the control. Table 5 gives the values of dynamic moduli of elasticity of various specimen.

\subsection{Ultrasonic Pulse Velocity}

Average pulse velocity across concrete with specimen containing $10 \%$ and $20 \%$ 
sand replaced with limestone dust was observed to be 5.2 and $5.4 \mathrm{~km} / \mathrm{s}$ respectively as compared to an average velocity of around $4.8 \mathrm{~km} / \mathrm{s}$ for control mixes. Hence ultrasonic pulse velocity in the case of concrete with $10 \%$ and $20 \%$ sand replaced with limestone dust was observed to be $10 \%$ to $12 \%$ higher than the control mixes. Higher pulse velocities are certainly due to better quality, higher density and reduced voids in the high strength concretes containing partial replacement of limestone dust with sand, as compared to the control mixes. The ultrasonic pulse velocities observed for different concretes are given in Table 3.

\subsection{Density of Hardened Concrete}

The average saturated and oven-dried densities for SCC with blended cement and containing $10 \%$ and $20 \%$ sand replacement with stone dust are observed to be 2589 and $2461 \mathrm{~kg} / \mathrm{m}^{3}$ respectively, as compared to control mixes which were 2460 and $2397 \mathrm{~kg} / \mathrm{m}^{3}$, respectively. Hence the saturated and dry densities of SCC with blended cement and containing $10 \%$ and $20 \%$ sand replacement with stone dust are observed to be about $3 \%$ to $4 \%$ higher than the control mixes. It is due to better hydration and packing of finer materials in SCC with blended cement and containing $10 \%$ and $20 \%$ sand replacement with stone dust. In the presence of higher content of cementitious material and the low w/c ratios, most of the unhydrated cementitious material acts as filler to densify the concrete, whilst the hydration process continues over longer duration.

\subsection{Initial Surface Absorption (ISAT)}

Results of ISAT are given in Table 5. Initial surface absorption for SCC with blended cement and containing $10 \%$ and $20 \%$ sand replacement with stone dust are observed to be lower as compared to the control. Reduction of surface absorption up to $20 \%$ was observed. The values are compared with the guidelines given by the Concrete Society Technical Report \# 31 [12].

\subsection{Sulphate and Chloride Resistance}

Loss of weight when specimen were subjected to HCL solution was observed to be $8 \%$ for control mix as compared to $3 \%$ to $3-1 / 2 \%$ for SCC with blended cement and containing $10 \%$ and $20 \%$ sand replacement with stone dust. Similarly for $\mathrm{H}_{2} \mathrm{SO}_{4}$ solution, the weight loss for control was $6 \%$ as compared to $2 \%$ for $20 \%$ replacement of sand with stone dust. Therefore, the performance of SCC with blended cement and containing $10 \%$ and $20 \%$ sand replacement with stone dust are observed to be two to three times better in acidic environment and around three times better in sulphate environment as compared to control mixes.

\subsection{Shrinkage}

Shrinkage of all specimen was observed to be similar for almost all specimen. No appreciable difference in shrinkage of specimen cast from SCC with blended cement and containing $10 \%$ and $20 \%$ sand replacement with stone dust are 
observed as compared to control mixes over a period of 90 days.

\section{Conclusion}

Concrete with stone dust induced higher workability thereby satisfying the selfcompacting concrete performance with higher slump flows. Due to the pozzolanic and filling effects of the rock dust, there is more cementitious material formed with a dense structure with highly impermeable concrete formed through pore refinement and reduced sorptivity. SCC with blended cement and containing $10 \%$ and $20 \%$ sand replacement with stone dust can be designed for compressive strengths of $60 \& 80 \mathrm{MPa}$ like high strength concrete with ordinary Portland blended cement. SCC with blended cement and containing $10 \%$ and $20 \%$ sand replacement with stone dust are observed to develop $10 \%$ to $13 \%$ higher compressive strengths, $7 \%$ to $9 \%$ higher flexural strength, $5 \%$ to $8 \%$ higher static moduli of elasticity with values up to $40,000 \mathrm{~N} / \mathrm{mm}^{2}$, similarly higher values for dynamic moduli with about $4 \%$ to $5 \%$, about $4 \%$ to $8 \%$ higher pulse velocities, $3 \%$ to $4 \%$ higher density, up to $20 \%$ reduced permeability, similar shrinkage and two to three times improved sulphate and acid resistance as compared to control specimen were observed. Better strengths and improved durability of such SCC with blended cement and containing $10 \%$ and $20 \%$ sand replacement with stone dust is likely to make it a more acceptable material for major construction projects. Sulphate resistance of concrete containing stone dust is better than that of control specimen. This is due to the active $\mathrm{SiO}_{2}$ (almost $60 \%-75 \%)$ in rock dust react with the $\mathrm{Ca}(\mathrm{OH})_{2}$ in concrete to form secondary calcium silicate hydrate and make it chemically stable and structurally dense thereby enhancing the impermeability of concrete. High Strength SCC with partial replacement of sand with stone dust will also help in consuming large volumes of this industrial waste thereby reducing its disposal problems along with resulting into cheaper cements with stronger and durable characteristics.

\section{References}

[1] Felix Kala, T. (2013) Effect of Granite Powder on Strength Properties of Concrete. International Journal of Engineering and Science, 2, 36-50.

[2] Hameed, M.S. and Sekar, A.S.S. (2009) Properties of Green Concrete Containing Quarry Rock Dust and Marble Sludge Powder as Fine Aggregate. ARPN Journal of Engineering and Applied Sciences, 4, 83-89.

[3] Kibriya, T. (2006) Performance of Blended Cement in High Strength Self Compacting Concrete. ASCE Structures Congress 2006, Joint ASCE/SEI Conference, 18-20 May 2006, St Louis, Missouri, 1-7.

[4] Goodier, C.I. (2003) Development of Self Compacting Concrete. Proceedings of the Institution of Civil Engineers Structures \& Buildings, 156, 405-414. https://doi.org/10.1680/stbu.2003.156.4.405

[5] Khayat, K.H. and Guizani, H. (1997) Use of Viscosity-Modifying Admixtures to Enhance Stability of Fluid Concretes. ACI Materials Journal, 94, 332-340.

[6] Collepardi, M, Ogoumah, J.J., Olagot, Skarp, U. and Troli, R. (2002) Influence of 
Amorphous Colloidal Silica on the Properties of Self Compacting Concretes. Proceedings of the International Conference "Challenges in Concrete ConstructionInnovations and Developments in Concrete Materials and Construction", Dundee, 9-11 September 2002, 473-483.

[7] Loo, Y.C., Nimityongskul, P. and Karasudhi, P. (1984) Economical Rice Husk Ash Concrete. CIB Journal, August, 1512-1517.

[8] Kibriya, T. and Baig, N. (2005) High Performance Concrete with Blended Cements Using Agrowastes. Proceedings of MCMat 2005, Joint ASCE/ ASME/ SES Conference on Mechanics and Materials, Baton Rouge, Louisiana, 1-3 June 2005, 112-1-5.

[9] Kibriya, T. and Khan, S. (2005) High Performance Concrete Pavements Using Agrowaste Blended Cement. Proceedings of MCMat 2005, Joint ASCE/ASME/SES Conference on Mechanics and Materials, Baton Rouge, Louisiana, 1-3 June 2005, 60-1-4.

[10] Kibriya, T. and Khan, S. (2005) Performance of Ecologically Friendly Waste in High Strength Concrete. IV Regional Conference on Civil Engineering Technology, Joint ASCE/ ESIE Conference, 7-9 June 2005, Cairo, 1-4.

[11] Teychenne, D.C, Franklin, R.E. and Erntroy, H.C. (1988) Design of Normal Concrete Mixes, (Replacement to Road Note.4), Department of Environment-Transport and Road Research Laboratory, London.

[12] ACI Compilation \# 32, High Performance Concrete.

[13] Nawy, E.G. (1996) Fundamentals of High Strength High Performance Concrete. Longman.

Submit or recommend next manuscript to SCIRP and we will provide best service for you:

Accepting pre-submission inquiries through Email, Facebook, LinkedIn, Twitter, etc. A wide selection of journals (inclusive of 9 subjects, more than 200 journals)

Providing 24-hour high-quality service

User-friendly online submission system

Fair and swift peer-review system

Efficient typesetting and proofreading procedure

Display of the result of downloads and visits, as well as the number of cited articles

Maximum dissemination of your research work

Submit your manuscript at: http://papersubmission.scirp.org/

Or contactwjet@scirp.org 